\title{
Epidemiology, Structure and Disease Burden of SARS-CoV-2 in Different States of India Using SWOT Analysis
}

Dr. Amresh Kumar Singh ${ }^{1 *}$, Mr. Indra Prasad Adhikari ${ }^{2}$, Mr. Vivek Gaur ${ }^{3}$, Ms. Sanpreet Kaur ${ }^{4}$, Dr. Satya Prakash ${ }^{5}$, Dr. Raj Kumar ${ }^{6}$, Dr. Rajju Tiwari ${ }^{7}$

\author{
${ }^{\mathrm{T}}$ Assistant Professor \& Head/In-Charge COVID-19 Lab, Department of Microbiology, Baba Raghav Das Medical College, Gorakhpur, \\ Uttar Pradesh, India \\ ${ }^{2}$ Demonstartor, Department of Biochemistry, Baba Raghav Das Medical College, Gorakhpur, Uttar Pradesh, India-273013 \\ ${ }^{3}$ Junior Residents, Viral Diagnostic Research Laboratory, Department of Microbiology, Baba Raghav Das Medical College, \\ Gorakhpur, Uttar Pradesh, India \\ ${ }^{4}$ Microbiologist, Viral Diagnostic Research Laboratory, Department of Microbiology, Baba Raghav Das Medical College, Gorakhpur, \\ Uttar Pradesh, India \\ ${ }^{5}$ Assistant Professor and Head, Department of Biochemistry, Baba Raghav Das Medical College, Gorakhpur, Uttar Pradesh, India \\ ${ }^{6}$ Professor and Head, Department of Biochemistry, Baba Raghav Das Medical College, Gorakhpur, Uttar Pradesh, India \\ ${ }^{7}$ Demonstrator, Department of Biochemistry, Government Medical College, Datia, MP-475661
}

DOI: $10.36347 /$ sjams.2021.v09i03.004

| Received: 08.02.2021| Accepted: 22.02.2021| Published: 03.03.2021

*Corresponding author: Dr. Amresh Kumar Singh, MD

Abstract

Original Research Article

The severe acute respiratory syndrome coronavirus 2 (SARS-CoV-2), which causes corona virus disease 2019 (COVID-19), was first reported in Wuhan, China in December 2019. Most of the people infected with the COVID-19 experienced mild to moderate illness, fever, shortness of breath and recovered without requiring special treatment. Old age peoples and those with underlying medical problems like cardiovascular disease, diabetes, chronic respiratory disease, and cancer are more likely to develop serious illness. The case fatality rate (CFR) was lower than that of SARS or MERS, the scale of the COVID-19 contagion has caused more casualties than them. The epidemiological data was obtained from the Ministry of Health and Family Welfare, India, Wikipedia, and ICMR as well as different COVID-19 state portals using SWOT analysis (Strengths, Weaknesses, Opportunities, and Threats). The countries with the highest deaths were seen in the USA (1.007\%), followed by France $(0.95 \%)$, Brazil $(0.89 \%)$, Russia (0.36\%), and India $(0.106 \%)$. India was listed among deaths per million and the reason was, the average population of Indian is young with 94,61,901 cases, 88,47,600 recovered, 1,37,582 deaths and national recovery rate was highest ie. $93.81 \%$. The total CFR declined to $1.45 \%$, and $4,46,952$, total active cases in the country which was $4.74 \%$ of the total caseload. Among different states of India, the Maharashtra was listed as first with 16, 60,766 cases, 14,86,926 recovered and 43,554 deaths. Next states were: Karnataka; 9,12,340 cases and 12,038 deaths, Tamil Nadu: 8,10,080 cases and 12,024 deaths, Delhi; 6,19,618 cases and 10,337 deaths, Uttar Pradesh; 5,77,642 cases and 8245 deaths as on $30^{\text {th }}$ November 2020.

Keywords: COVID-19, SARS-CoV-2, pandemic, Coronavirus, case fatality rate, MoHFW, WHO.

Copyright $\odot 2021$ The Author(s): This is an open-access article distributed under the terms of the Creative Commons Attribution 4.0 International License (CC BY-NC 4.0) which permits unrestricted use, distribution, and reproduction in any medium for non-commercial use provided the original author and source are credited.

\section{INTRODUCTION}

The novel beta corona virus, severe acute respiratory syndrome corona virus 2 (SARS-CoV-2), which causes corona virus disease 2019 (COVID-19), was first reported in Wuhan Province of China in December 2019 [1,2]. Soon after, the virus caused an outbreak in China and has spread to the all over the world. According to the World Health Organization (WHO), the current outbreak of COVID-19 has nearly 70.72 million confirmed cases worldwide with more than $15,88,437$ deaths, as of first week of December 2020. The COVID-19 is a virus disease caused by a newly spread SARS-CoV-2. Most of the people infected with the COVID19 virus were experienced mild to moderate respiratory illness, fever, shortness of breath and recover without requiring special treatment. Old age peoples and those with underlying medical problems like cardiovascular disease, diabetes, chronic respiratory disease, and cancer are more likely to develop serious illness in this disease [3]. Coronaviruses circulates in some wild animals and has 
Amresh Kumar Singh et al; Sch J App Med Sci, Mar, 2021; 9(3): 312-321

the capability to transmit from animals to humans. These viruses can cause respiratory symptoms in humans, along with other symptoms of common cold and fever [4].

Based on the phylogenetic analysis, COVID19 belongs to a distinct clade of beta-coronavirus similar to human SARS and Middle East Respiratory Syndrome Coronavirus (MERS-CoV), two species out breaking in the latest decade and causing severe human deaths [5]. Despite the estimated fatality rate of COVID-19 was lower than that of SARS or MERS, the scale of the COVID-19 contagion has caused more casualties than either of them [6].

The year 2020 was begins with a huge number of challenge called COVID-19 in India too. India is the second most populous country in the world after China. India is also an immediate neighbour to China and hence more possible to the viral disease spread. The country reported its first confirmed case on $30^{\text {th }}$ January 2020 from the Kerala state, which was directly linked to Wuhan, the epicentre of COVID-19 outbreak. A 76year-old man tested positive for SARS-CoV-2 was the first death from COVID-19 in India on $11^{\text {th }}$ March 2020, reported from Kalaburagi, Karnataka [7]. The COVID-19 was increased day by day in India and among different states. In mid of August and first week of September in India, with over more than 90,000 plus cases reported per day and have since come down to below 40,000 in mid-November, highest number of cases $(97,399)$ recorded in the country in a single day on $10^{\text {th }}$ September, 2020 and $8^{\text {th }}$ September 2020 highest number $(1,133)$ of COVID-19 related deaths. The situation of COVID-19 pandemic became critical to control day by day the interference of local administrators, state governments and central government as well. The entire world was not only losing their social economical strengths, but also lost millions of lives till date in several countries including India [8]. In the present scenario health ministry of India has said that 10 states and union territories have the maximum number of cases around 75 percent. These states and Union Territories are Maharashtra, Andhra Pradesh, Tamil Nadu, Karnataka, Delhi, Uttar Pradesh, Kerala, Odisha, West Bengal, and Chhattisgarh [9]. Maharashtra has the highest number of cases in the country, even more than total number of cases recorded in China. Till November $30^{\text {th }} 2020$, a total of 1,66,076 cases notified among which 1,29,746 active and 14,86,926 recovered. A total of 43,554 people have died in the Maharashtra due to COVID-19 related illnesses [10].

\section{DATA SOURCE}

We obtained the epidemic data from the Indian COVID-19 data available in public domain by the government of India. The three primary sources of the data were the Ministry of Health and Family Welfare, India, Wikipedia, and Indian Council of Medical
Research before SWOT analysis (Strengths, Weaknesses, Opportunities, and Threats) [11-14]. There are generally three kinds of methods to study the law of infectious disease transmission. Statistical modeling based on random process, time series analysis and other statistical methods. The third is to use data mining technology to obtain the information in the data and find the epidemic law of infectious diseases [15].

\section{Clinical features and diagnosis}

The symptoms of COVID-19 remain very similar to those of the other respiratory epidemics in the past, which include SARS and MERS, but here wide range of symptoms includes mild fever to septic shock. Some intestinal disturbances were reported with the other epidemics, but COVID-19 was devoid of such symptoms. When examined, unilateral or bilateral involvement compatible with viral pneumonia was observed in the patients, and bilateral multiple lobular and sub-segmental consolidation areas were observed in patients hospitalized in the intensive care unit. The comorbid patients showed a more severe clinical course than predicted from previous epidemic. The diagnosis of COVID-19 includes the complete history of travel and later confirmed with laboratory testing. It is more preferable to choose serological screening, which can help to analyze even asymptomatic infections; several serological tests are in progress for SARS-CoV-2 [16, 17].

\section{Specimen collection and storage}

Nasal swab and/or throat swab specimens is to be collected as per Government of India guidelines using dacron or polyester flocked swabs. It should be transported to the laboratory at a temperature of $4^{\circ} \mathrm{C}$ and stored between $4-8^{\circ} \mathrm{C}$ on the basis of the number of days. Both nasopharyngeal and oropharyngeal swabs should be placed in the same container. Bronchoalveolar lavage and nasopharyngeal aspirate should be collected in a sterile container and transported similarly to the laboratory by maintain a temperature of $4^{\circ} \mathrm{C}$.

\section{Transmission}

SARS CO-2 virus can be spread through direct exposure to infected animals, human-to-human, and environmental contamination. Firstly, the initial cases of COVID-19 were associated with direct contact to infected animals and this was experienced at the seafood marketplace in Wuhan, China [18]. Moreover, the virus can spread from one person to another, and this is considered to be the main form of transmission [19]. In addition, while the newer patients had no exposure to the market and still got the virus from the humans, so, there was an increase in the outbreak of this virus through human-to-human transmission, with the fact that it has become widespread. This confirms the fact similar to the previous epidemics, including SARS and MERS, that this Coronavirus exhibited potential human-to-human transmission, as it was recently 
Amresh Kumar Singh et al; Sch J App Med Sci, Mar, 2021; 9(3): 312-321

declared a pandemic by WHO [20]. The respiratory droplets were the major carrier for corona virus transmission. In some instances, there was a possible spreading in closed areas because of raised aerosol concentrations [21]. The physics of exhaled air and flow physics have generated hypotheses about possible mechanisms of SARS-CoV-2 transmission through aerosols [22]. These theories suggested that by a number of respiratory aerosols generate microscopic size $(<4.5 \mu \mathrm{m})$ by evaporating, and normal breathing and talking results in exhaled aerosols in the environment. Thus, a susceptible person could inhale aerosols, and could become infected if the aerosols contain the virus in sufficient quantity to cause infection within the recipient [23]. The virus can also spread through touching contaminated surfaces. This happens when it touches these surfaces and then transfers the virus to mucous membranes in the upper parts of the body, especially mouth, eyes, or nose [24]. Hence, COVID-19 can be transmitted in different ways, and this calls for the need for individuals to be aware of its transmission so as to keep them safe all the time.

\section{COVID-19 structure, genome and its variations}

COVID-19 is a spherical or pleomorphic enveloped protein particles containing single-stranded (positive-sense) RNA associated with a nucleoprotein within a capsid comprised of matrix protein. The envelope bears club-shaped glycoprotein projections. Some coronaviruses also contain a hem agglutininesterase protein [25].

Their size is highly variable and generally is an average diameter of $120 \mathrm{~nm}$. Extreme sizes are known from 50 to $200 \mathrm{~nm}$ in diameter [26]. The total molecular weight is on average $40,000 \mathrm{kDa}$. They are enclosed in an envelope embedded with a number of protein molecules [27]. The lipid bilayer envelope, membrane proteins, and nucleocapsid protect the virus when it is outside the host cell [28].

Corona viruses contain the largest genomes structure between 26.4 to 31.7 kilo bases among all known RNA viruses, with Guanine and Cytosine contents varying from $32 \%$ to $43 \%$ of its total overall genomic material. The variable numbers of small ORFs and RDRP gene are present between the various conserved genes (ORFlab, spike, envelope, membrane and nucleocapsid) and the genome terminal has a $5^{\prime}$ methylated cap and a $3^{\prime}$ polyadenylated tail downstream to the nucleocapsid gene in different Coronavirus lineages. The viral genome contains distinctive features, including a unique $\mathrm{N}$-terminal fragment within the spike $[\mathrm{S}]$ protein envelope (E], membrane (M]. Genes for the major structural proteins in all coronaviruses occur in the 5-3 order as S, E, M, and N [Figure 1] [29]. The E proteins facilitate assembly and release of the virus but also have other functions. For instance, the ion channel activity in SARS-CoV-2, E protein is not required for viral replication but is required for pathogenesis [30]. The $\mathrm{N}$ protein constitutes the only protein present in the nucleocapsid. It is composed of two separate domains, an N-terminal domain (NTD) and a C-terminal domain (CTD), both capable of binding RNA in vitro, but each domain uses different mechanisms to bind RNA. It has been suggested that optimal RNA binding requires contributions from both domains and it also seen $\mathrm{N}$ protein is also heavily phosphorylated [31]. Recent SARS-CoV-2 work has also shown that the membrane exopeptidase ACE enzyme (angiotensin-converting enzyme) functions as a COVID-19 receptor to enter the human cell especially through it [32].

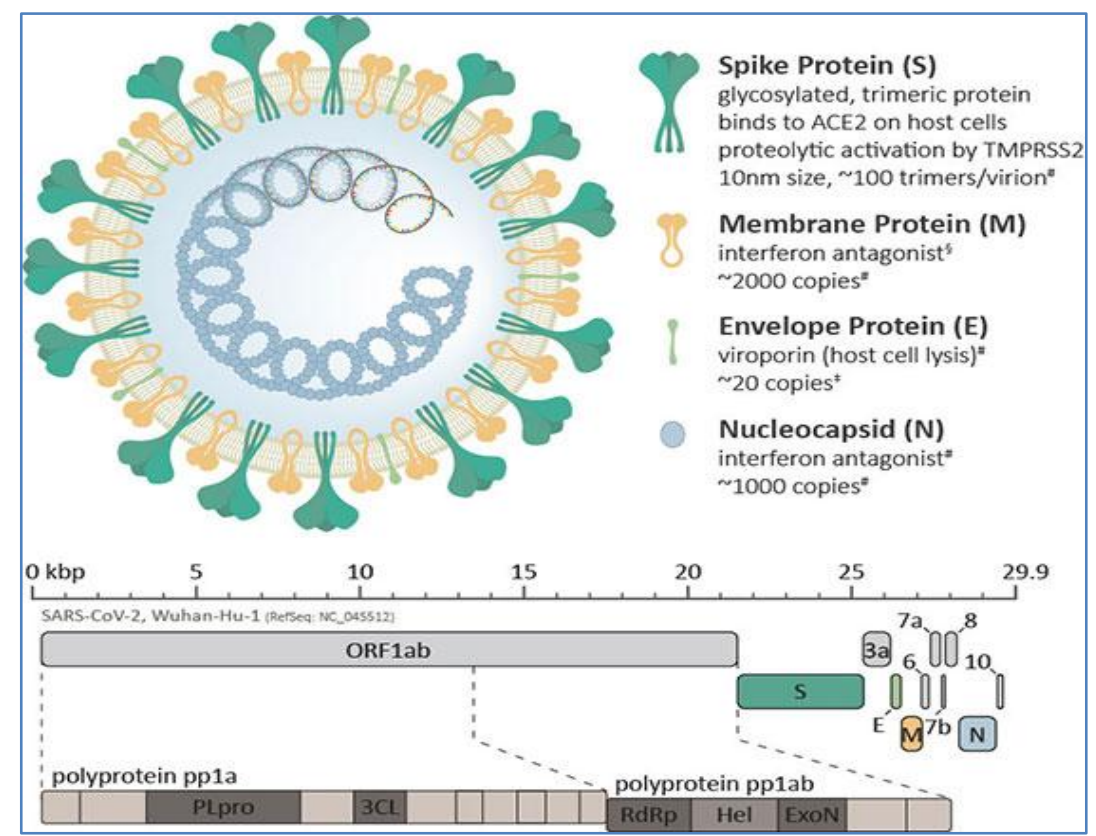

Fig-1: COVID-19 virus genome: Structure in details 
Amresh Kumar Singh et al; Sch J App Med Sci, Mar, 2021; 9(3): 312-321

\section{Genetic variation in SARS-CoV-2}

Genetic variation in SARS-CoV-2 was noted to different countries and between geographical locations within the same country. The native sequence of the full-genome of the SARS-CoV-2 was identified soon after the spread of the virus disease in Wuhan province of the people republic of China in December 2019. When COVID-19 quickly spread whole over the world, sequencing of the COVID-19 virus genome was analysis from infected patients to compare the sequence with the original viral sequence. The genomic sequence of SARS-CoV-2 of the first two COVID-19 patients diagnosed in Italy during January and February 2020 already showed mutations compared to the original virus sequence established in China. The variations in the genomic sequences were also observed when sequencing data from viral isolates of patients from other European and North American countries were compared with each other and with native viral sequence [33]. A total of 12,343 SARS-CoV-2 sequences isolated in six geographic areas from 50 different countries, including 1,062 sequences from Asia, 4,060 from North America, 99 from South America, 6,012 from Europe, 1,028 from Oceania, and 82 from Africa regions [34]. To analyze mutations based on countries, the data of 28 countries in which more than 30 SARS-CoV-2 sequences are available, among the 50 countries. A large number of mutations may occur on all of the SARS-CoV-2 genes and have broad effects on diagnostic kits, vaccines, and drug developments.

\section{RESULTS}

\section{Global Scenario of SARS-CoV-2}

When the COVID-19 spread out in the Chinese city of Wuhan, most of the cases were reported from the United States of America, India Brazil, and Russia. While some nations like people republic of China and Republic of South Korea, New Zealand, Australia, Iceland have successfully been able to flatten the pandemic curve, other nations are finding it difficult to achieve the same. In the absence of any effective therapy medicine/vaccine against COVID-19, the resilience of the health care infrastructure and health professionals were being put to test [35].

Though, COVID-19 has spread to as many as 205 countries across the world, infected 71.7 million people and causing over 1.5 million deaths till $30^{\text {th }}$ November 2020 and the number was increased day by day rapidly, mainly among United States, India, and European unions. These countries have taken various measures, including national wide lockdown, to contain the spread but have not fully successful. South Korea has been able to contain and drastically reduced the spread of the virus without imposing a nationwide lockdown or any draconian measures so this region many country follow South Korea model [36]. The 2020 corona virus pandemic is the largest public health threat in a century and perhaps the most consequential event since the Second World War. The Carnegie Endowment for International Peace in a web discussion dissected, if the world is in peril and if, there is a way out. It was noted that the COVID-19 was not only an epidemiological threat, but a systemic crisis affecting the political, social, and economic structures of modern world. It raised the issue, if the world could learn any lesson from the Great Influenza of 1918. Since there, does not seem to be finality in the immediate horizon and governments around the world begin to open up, debates centre on strategies for mitigation, risk management, and for preparation for the possibility of a second and third wave. Many counties have already faced second wave of this pandemic especially in European Union and African countries.

It further probed, if there are reasonable expectations for the development of a vaccine. The crucial point is to sculpt a long-term international strategy that combats the virus and safeguards economies at the same time [36]. The number of infected persons from the COVID-19 crossed 71 million till November $30^{\text {th }}$ and more than 1.5 million deaths worldwide in around 213 counties [37]. Among the countries with the highest deaths were seen in the most populous countries such as the USA, India, and Brazil. Out of these, most number of deaths per million was maximum in USA around $1.007 \%$, France $0.95 \%$, Brazil $0.89 \%$, Russia $0.36 \%$, and India $0.106 \%$. Out of these countries, India was listed later among number of deaths per million populations, and the reason behind this was the average population of Indians was young.

In less than few months since virus spread in the world outbreak, the USA recorded more COVID-19 related deaths than any other country. On November $30^{\text {th }}$ the USA officially infected people was $1,33,93,166$ confirmed cases, 2,66,932 death, and 20,65,030 recovered, most affected state in USA was Texas 12,25,624, California 12,16,856, Florida 9,92,660, and Illinois 7,20,114. The second most affected county was India with 94,61,901 cases, 88,47,600 recovered, $1,37,582$ deaths and national recovery rate was very good $(93.81 \%)$ than other most affected countries with total fatality rate declined to reach $1.45 \%$ and 4,46,952 total active cases, which was total $4.74 \%$ of the total caseload in the country. The third most affected county in the world was Brazil; national caseload was 63, 14,740 out of this $1,72,833$ died and Brazil was the having second highest death toll from COVID-19. Though, the elderly people and those with pre-existing medical conditions have proved to be more vulnerable, the virus has affected all age groups of all identities, including children afflicted what remains a littleunderstood inflammatory syndrome. In an effort to contain the contagion, many countries have closed their borders, businesses, issued economic stimulus packages to rescue those severely affected and to check the soaring unemployment rate. These did not prevent some countries to slip into depression. The social distancing, 
Amresh Kumar Singh et al; Sch J App Med Sci, Mar, 2021; 9(3): 312-321

wearing masks, staying at home, work from home, elearning, etc. were some measures that divided some societies along partisan lines. These became soon the "new normal".

India too was continuing to struggle combating the virus as the numbers continue to surge. The total numbers of infected cases as of $30^{\text {th }}$ November was 94 , 61,901 with 1,37,582 fatalities [35]. India has emerged as Asia's new hotspot for COVID-19. Since, the lockdown cannot be kept indefinitely and economic activities have to resume, some relaxation have already been announced by the government of India. Currently, many island counties like New Zealand, Taiwan, Australia, and Iceland had been able to bring infections down and open up their countries internally. Other island nations were also able to almost entirely prevent an COVID-19 outbreak.

\section{Indian Scenario of SARS-CoV-2}

The Novel Corona Virus (COVID-19) earlier known only as the Wuhan virus, initially expanded around circle in Republic of South Korea, Japan, Italy, Iran and finally spreading its routes to India. Now days, India is second most affected county in the world after USA in COVID-19 infection. It was given the name novel because it is a never seen before mutation of animal corona virus. As of now, virus spread source was unknown. It was assumed that the virus might be linked with a wet market (with seafood and live animals) from Wuhan that was not complying with health and safety regulations. The Wuhan wet market has since been closed down indefinitely [38].

The first case of COVID-19 in India was reported on January $30^{\text {th }} 2020$; the infected patient was a student who had returned from Wuhan city of China to Kerala. Thereafter, only 2 more cases were reported in February [39]. Subsequently, more cases came to the forefront in the month of March, and there has been a surge in the number of cases since the second half of April 2020. As of $30^{\text {th }}$ November 2020, India was the second largest affected county in the world after USA according to the Ministry of Health and Family Welfare (MoHFW), a total of confirmed cases 94,61,901, recovered 88,47,600, and deaths 1,37,582 have been reported from 32 states/union territories [40]. The outbreak has been declared as an epidemic in more than a dozen states and Union Territories, where provision of the Epidemic Diseases Act, 1897 have been invoked, and all things have been shut down. India has suspended all tourist visas, as a majority of cases were linked to other countries [41]. The Govt. has also applied lockdown of 75 districts across the country, where confirmed COVID-19 cases have been reported till $30^{\text {th }}$ June 2020 [42]. Most of the cases have been reported from the states of Maharashtra, Tamil Nadu, Delhi, and Gujarat, the MoHFW have reported, translating into a case-fatality rate of $1.4 \%$ [40].
An estimate released by the Indian Council of Medical Research and Home Ministry on November, 2020 revealed that out of total cases, $76 \%$ were male. People younger than 40 years and older than 60 years accounted for $47 \%$ and $19 \%$ of cases, respectively. On the contrary, $63 \%$ of all-over the deaths were occurred in age more than 60 years. The CFR in 3 age groups, namely, $50<60$ years, $>60-70$ years, and $>70$ years were $0.40 \%, 2.36 \%$, and $8.89 \%$, respectively. Moreover, $86 \%$ of the deaths were seen in people with underlying comorbidities like, diabetes mellitus, hypertension, kidney disease and/or cardiovascular disease. Although the overall mortality rates vary from one nation to another, being as low as $0.7 \%$ in Germany to as high as $10.8 \%$ in Italy [43].

\section{State-wise scenario of SARS-CoV-2}

India, a country of 1.3 billion people, has reported date case 94, 61,901 confirmed COVID-19 cases November 2020 from the first reported case in Kerala [44]. In a similar duration from the first case, the USA reported more than 4,00,000 cases and China more than 3,500, Spain and Italy reported more than 1,50,000 confirmed COVID-19 cases. To gain some more perspective, the USA population was around onefourth of the Indian population. Therefore, according to the reported data so far, India seems to have managed the COVID-19 pandemic better as compared to many other developed countries. One argue that, India has conducted too few tests as compared to its population size, this was the major fact of show less number of COVID-19 cases in India initially and in at the month of May-June the COVID-19 testing was rapidly increased, due to this reason the number of positive cases were gradually increased [45].

India may have seen less COVID-19 cases till November end, but the war is not over yet. There were many states like Maharashtra, Delhi, Tamil Nadu, Madhya Pradesh, Rajasthan, Gujarat, Uttar Pradesh, and West Bengal still at high risk of COVID-19 [Figure $2 \&$ 3 ]. These states may see a huge number of confirmed COVID-19 cases in days by day if preventive measures are not implemented properly. On the positive side, Kerala and Delhi has set example how to control infection spread. We hope that, India can be free of COVID-19 with a strong determination as already shown by the central and respective state Governments. The Maharashtra state was listed among highly infected state with 16,60,766 cases, 14,86,926 recoveries and 43,554 deaths, while the active cases are 1,29,746. Other state with respect to the COVID-19 infection, and next the states Karnataka 9,12,340 confirmed cases and 12,038 deaths, Tamil Nadu 8,10,080 cases and 12,024 deaths, Delhi 6,19,618 cases and 10,337 deaths, Gujarat 2,38,205 cases and 4,258 deaths, Madhya Pradesh 2,34,331 cases and 3,514 deaths, Uttar Pradesh 5,77,642 cases and 8,245 deaths, and West Bengal 5,41,624 confirmed cases and 9,473 deaths as of on $30^{\text {th }}$ November 2020. 


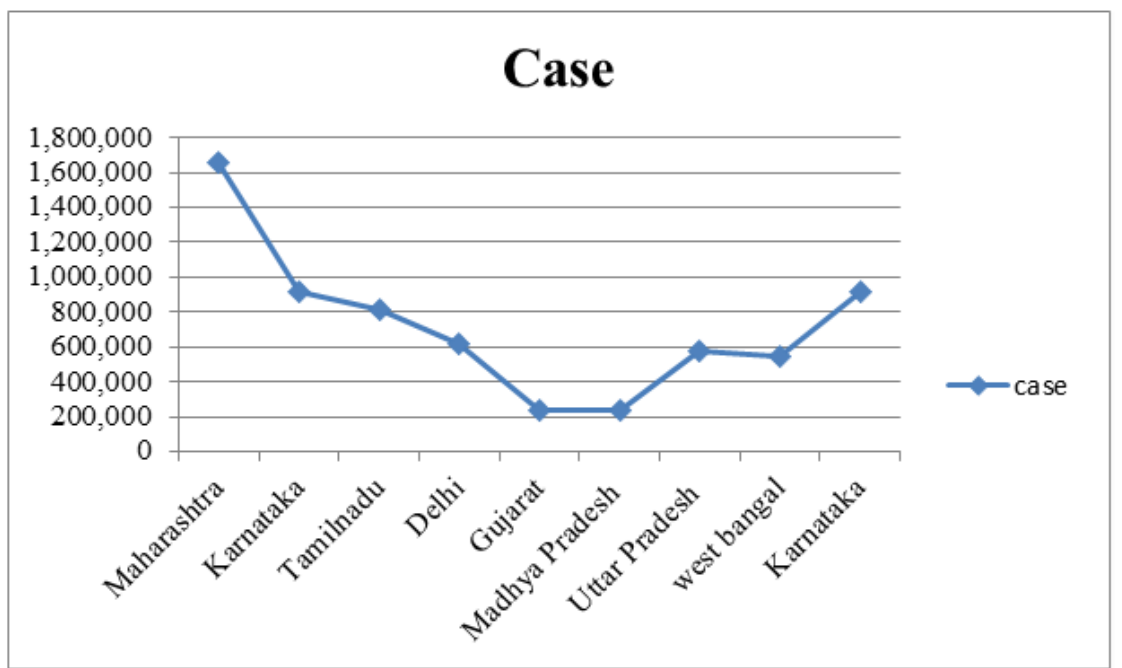

Fig-2: State wise scenario of COVID-19 cases in major states of India

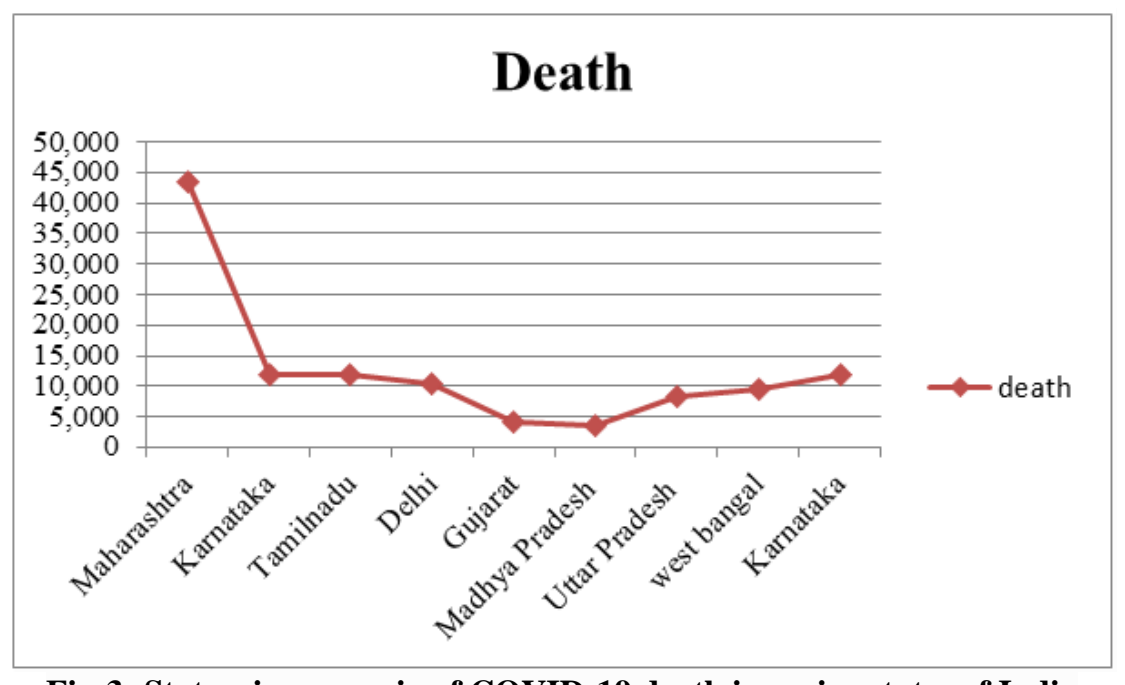

Fig-3: State wise scenario of COVID-19 death in major states of India

\section{Maharashtra}

Mumbai is the second most populous city in India after Delhi, and the seventh most populous city in the whole world with a population is around 20 million. As per Indian government population data of 2011, Mumbai was the most populous and dense city in India with an estimated city proper population of 12.5 million living under Municipal Corporation of Greater Mumbai. Mumbai is the centre of the Mumbai Metropolitan Region, the sixth most populous metropolitan area in the world with a population of over 23.64 million. The situation in Maharashtra was very severe with respect to the active number of cases. As of November $30^{\text {th }} 2020$, the total numbers of infected cases were 16,60,766, with 14,86,926 recovered, and 43,554 deaths [Figure $2 \& 3$ ]. In Mumbai, the COVID-19 cases were increased day by day till November 2020, and there were several reasons behind that situation, like insufficient land for maintaining social distancing, dense population, common toilets, shared utilities, slums, majority of unclean area, and humid atmosphere [46].
In Maharashtra, $21.19 \%$ of cases were in the age group between $31-40$ years and $18.40 \%$ of cases in 21-30 years age group in $10.09 \%$ of the total cases are age group between $61-70$ years and the mortality rate was $7.86 \%$, which increased up to $12.15 \%$ among people in 71-80 years group. Approximately $15.57 \%$ and $14.69 \%$ cases were in the age group between $81-90$ and 91-100 years respectively. Till date, mortality rate among females patient was very low $\sim 5.13 \%$ as compared to the male that is $8.54 \%$. The ratio of male and female patients in the state was 38:62. In Maharashtra the CFR was high as compared to other state; it was around $2.63 \%$ [47]. The local administrative are failing to control exponential increase in number of COVID-19 cases, but few months ago the migration stop the infection rate was decrease in Mumbai.

\section{Karnataka}

The first case of the COVID-19 pandemic in the Indian state of Karnataka was confirmed on $9^{\text {th }}$ March 2020. Karnataka was the first state to report first COVID-19 death on $11^{\text {th }}$ March 2020 in India. 
Amresh Kumar Singh et al; Sch J App Med Sci, Mar, 2021; 9(3): 312-321

Karnataka became the first in India to implement the provisions of the Epidemic Diseases Act, 1897, which are set to last for a year, to curb the spread of the disease [48]. Till date, there have been 9,13,448 confirmed cases with 8,97,204 recoveries and 12,039 deaths [49]. On $9^{\text {th }}$ March 2020, the Karnataka state government issued a circular ordering the closure of kindergartens and primary classes in all schools in the state after the state reporting its first death, issued a directive to close all public places with high footfall like malls, universities and colleges, movie theatres, night clubs, marriages and conferences, as a precautionary measure amid the growing scare of the COVID-19 [50]. Further, The State closed its borders with Kerala for vehicular traffic in the wake of six people testing positive for corona virus in bordering Kasargod of Kerala [51].

\section{Delhi}

The first case of the COVID-19 pandemic in the Indian capital Delhi was reported on 2 March 2020. Delhi has the third highest number of confirmed cases of COVID-19 pandemic

in India after Maharashtra and Karnataka, Delhi, being a high population-density state, has already observed 6,19,618 cases and 10,337 deaths due to COVID-19. The situation in Delhi is very severe behind this situation Thousands of migrants from Uttar Pradesh and Bihar gathered in Anandvihar Bus Station on $29^{\text {th }}$ March 2020 [52]. More than 3000 people from a religious gathering in Nizamuddin Markaz Mosque were quarantined after suspected contact with infected people. Approximately 1,300 Tablighi Jamatis were found gathered, including foreigners in Markaz [53]. These people travelled in different locations of the country and sudden after that number of case in country rise Delhi was the first Indian state facing second wave of corona virus. The daily infection-rate (DIR) has seen a up-ward trend in the past few days. Except for the last few days, the line-graph rise upward of observed active infected patients is reflecting an exponential growth, especially after second wave of COVID-19. The observed infection-rate was in between 0.15 to 0.23 , which was considered medium, considering the preventive measures were already in place. The medium infection-rate may suggest that there could be many people who are in the community without knowing that they are already infected with the COVID-19. The state could be heading to community spreading of COVID19 in large scale.

\section{Tamil Nadu}

The first case of the COVID-19 pandemic in Tamil Nadu was reported on $7^{\text {th }}$ March 2020. Tamil Nadu has the fourth highest number of confirmed cases in India after Karnataka, Delhi, and Maharashtra. All 37 districts of the state were affected by the pandemic, with capital district Chennai being the worst affected. The cumulative infected cases in Tamil Nadu were 8, 10,080 cases, and 12,024 deaths. The state has observed a high daily infected-rate of more than 0.7 in some days in March. Tamil Nadu was one of the states where the effect of lockdown is visibly seen from the declining daily infected-rates in the last few weeks. The linegraph of observed active infected patients is still showing an increasing trend till date. However, it is now far below the curve based on the estimated $75^{\text {th }}$ percentile of observed infected-rates. Based on the logistic model; the cumulative infected cases may be saturated.

\section{Uttar Pradesh}

Uttar Pradesh is the most populated state in the India. The COVID-19 first confirmed case in Uttar Pradesh, India was seen on $4^{\text {th }}$ March 2020 , with the first positive case in Ghaziabad. As of $30^{\text {th }}$ November 2020 , the state has 5,51,179 confirmed cases, resulting in 7,877 deaths and 5,20,637 recoveries [54]. The CFR in the state stands at $1.4 \%$. The eight districts of Uttar Pradesh that lie in the National Capital Region (NCR) account for over $25 \%$ or one-fourth of the active COVID-19 cases and nearly $11 \%$ of the deaths, according to official data of Uttar Pradesh health ministry Uttar Pradesh. Gautama Buddha Nagar, Ghaziabad, Hapur, Bulandshahar, Meerut, Muzafarnagar, Baghpat and Shamli districts were a part of the NCR, a wider region that also comprises districts from Haryana, Rajasthan and entire Delhi contributed a lot in COVID-19 cases. Meerut has the highest number of 2,102 active cases among these eight districts, after that Gautam Buddhnagar $(1,401)$, Ghaziabad $(1,195)$, Muzaffarnagar (431), Bulandshahar (304), Shamli (168) Hapur (167) and Baghpat (149), according to the official data of the government of Uttar Pradesh. The State has so far recorded 7,877 deaths linked to COVID-19, with 819 (10.92\%) of them being recorded in the NCR districts, showed in government date of Uttar Pradesh data, which was updated every 24 hours duration, also showed that so far, 49,113 COVID-19 patients have recovered, with 73,046 (14.87\%) such patients being in the eight NCR districts of the state [55].

\section{Future prospects and on-going disease burden}

There are a number of possible futures, all dependent on how government's, people and society respond to COVID-19 and its economic aftermath. Hopefully, we will use this crisis to rebuild, produce something better and more humane.

The COVID-19 outbreak was proving to be an unprecedented disaster, especially in the most affected countries including China, India, Brazil, Italy, Iran and USA in all aspects, especially health, social and economic. It is too early to forecast any realistic scenario, but it has a strong impact worldwide. If high income countries, especially those already affected by the outbreak, seem to face a serious perspective, in lowincome countries there seem to be two possible 
Amresh Kumar Singh et al; Sch J App Med Sci, Mar, 2021; 9(3): 312-321

scenarios. In particular, in the worst-case scenario, when the COVID-19 outbreak occurred, the majority of countries were unprepared, with low resources allocated for affording the viral emergency and the consequences was catastrophic. In the best case scenario, similarly to the global outbreak of the SARS in 2003, also the COVID-19 has not affected Africa on a large scale in early phase, suggesting that respiratory viruses spread more effectively in the winter. Therefore, the southern hemisphere will be affected later in the year [56].

\section{Second strain (new strain) in United Kingdom}

The new variant of COVID-19 was detected in early December 2020 in Greater London, even as countries around the world intensified efforts to prevent transmission of an earlier mutated strain of the virus from the island nation. This mutant strain was 70 percent more infectious than original SARS-CoV-2 [57]. The new variant of COVID-19 spread in September 2020 and then circulated at very low levels in the population. The increase in cases linked to the new variant first came to mid-November in great London in United Kingdom (UK) was investigating that infection rates in Kent were not falling despite national restrictions. United Kingdom then investigated a cluster linked to this variant spreading rapidly into London and Essex in first week of December 2020.

The new UK variant of virus, which scientists have named "VUI-202012/01", includes a genetic mutation in the "spike" protein, which could result in coronavirus spreading more easily between people. It was first UK health secretary on $14^{\text {th }}$ December 2020 [58]. The government of India has banned travel from UK and track passenger arrived from last few weeks from the Britain. On $23^{\text {rd }}$ December, 22 peoples including 6 from Delhi tested positive for the UK travel history, and their samples were sent for genome sequencing [59]. The Reverse Transcription-Polymerase Chain Reaction (RT-PCR) the RT-PCR kit that used to detect COVID-19 gene detection where the mutation has happened for detecting virus may give out false negatives.

\section{Conclusion}

As per latest reports and data, there was a slight increase in daily cases in past few days in India with slight variation in total daily cases. After more than 3 months, less than thirty thousand cases were reported. On $30^{\text {th }}$ November 2020, a total of $94,61,901$ confirmed cases, 88,47,600 recovered, and 1,37,582 deaths have been reported from 32 states/union territories of India [40]. The Union Minister of Health, Govt. of India, assured that India is on the forefront of developing COVID-19 vaccines. Approximately, 300 million peoples are line-listed for COVID-19 vaccination in India, including healthcare, frontline workers and prioritized population groups. The MoHFW assured that, eight vaccine candidates including three indigenous vaccines are under process to be manufactured in India. The Union Minister of Education, Govt. of India has interacted with teachers, parents, students and urged students to continue their studies after following proper guidelines on COVID-19. The MoHFW has also chaired event that marking Universal Health Coverage Day and also emphasized the role COVID-19 has played in highlighting the need to build landmark healthcare systems in India ensuring equitable access to all [60].

\section{REFERENCE}

1. Wu F, Zhao S, Yu B, Chen YM, Wang W, Song ZG, Hu Y, Tao ZW, Tian JH, Pei YY, Yuan ML. A new coronavirus associated with human respiratory disease in China. Nature. 2020;579(7798):265-9.

2. Zhou P, Yang XL, Wang XG, Hu B, Zhang L, Zhang W, Si HR, Zhu Y, Li B, Huang CL, Chen HD. A pneumonia outbreak associated with a new coronavirus of probable bat origin. Nature. 2020;579(7798):270-3.

3. World Health Organization. Coronavirus. https://www.who.int/health-topics/coronavirus .

4. Ghosh P, Ghosh R, Chakraborty B. COVID-19 in India: State wise analysis and prediction. Med Rxiv. 2020.04.24.20077792.

5. De Wit E, Doremalen NV, Falzarano D, Munster VJ. SARS and MERS: recent insights into emerging coronaviruses. Nat Rev Microbiol. 2016;14:523-34.

6. Jiang S, Xia S, Ying T, Lu L. A novel coronavirus (2019-nCoV) causing pneumonia-associated respiratory syndrome. Cell Mol Immunol. 2020;17(5):554.

7. India's first coronavirus death is confirmed in Karnataka. Hindustan Times. 12 March 2020. Retrieved $27 \quad$ March $2020 . \quad$ https://www. hindustantimes.com/india-news/india-s-firstcoronavirus-death-in-karnataka-confirmed/story2ZJ6IuxJ38EiGndBq5pfHO.html

8. Kodge BG. A review on current status of COVID19 cases in Maharashtra state of India using GIS: a case study. Spatial Information Research. 2020; $1-7$.

9. Ministry of Health and Family Welfare. NITI Aayog. Healthy sates, progressive India: Reports on the ranks and union territories. Available online: Healthy-States-Progressive-India-Report.pdf

10. Ministry of Health and Family Welfare. Novel Corona Virus. Available online: https://main. mohfw.gov.in/disease alerts/novel-corona-virus.

11. Shrinivasan R, Rane S, Pai M. India's syndemic of tuberculosis and COVID-19. BMJ Global Health. 2020; 5:e003979.

12. COVID19 INDIA. Available online:https://www. covid19india.org/ [accessed 01.12.2020].

13. COVID-19 Tracker. Ministry of Health and Family Welfare, Govt. Of India. Available online: https://www.mohfw.gov.in/. Accessed November, 2020 . 
Amresh Kumar Singh et al; Sch J App Med Sci, Mar, 2021; 9(3): 312-321

14. National centre for disease control. Ministry of health and family welfare. Graphical illustration of data from COVID-19 cases in India. 2021. https://ncdc.gov.in/dashboard.php

15. Ma ZE, Zhou YC, Wang WD. Mathematical modelling and research of infectious disease dynamics. Virulence. 2013; 4(4):295-306.

16. Chen Y, Liu Q, Guo D. Emerging corona viruses: genome structure, replication, and pathogenesis. J Med Virol. 2020;92:418-423.

17. World Health Organization. Laboratory testing for 2019 novel Coronavirus (2019-nCoV). COVID-19: Laboratory and diagnosis. 19 March 2020. Available online: https://www. who. int/ publications/i/item/10665-331501.

18. Singhal TA. Review of Corona virus Disease-2019 (COVID-19).Indian J Pediatr. 2020; 87: 281-286.

19. Aluga MA. Coronavirus Disease 2019 (COVID-19) in Kenya: Preparedness, response and transmissibility. J Microbiol Immunol Infect. 2020; 53(5):671-673.

20. Holshue ML, DeBolt C, Lindquist S. First case of 2019 novel coronavirus in the United States. N Engl J Med. 2020; 382:929-936.

21. Anjorin AA. The coronavirus disease 2019 (COVID-19) pandemic: A review and an update on cases in Africa. Asian Pac J Trop Med. 2020; 13:199-203.

22. Mittal R, Ni R, Seo JH. The flow physics of COVID-19. J Fluid Mech.2020; 894,F2.

23. Gralton J, Tovey TR, McLaws ML, Rawlinson WD. Respiratory Virus RNA is detectable in airborne and droplet particles. J Med Virol. 2013; $85: 2151-2159$.

24. Harapan H, Itoh N, Yufika A, Winardi W, Keam S, Te H. Coronavirus disease 2019 (COVID-19): A literature review. Journal of Infection and Public Health. 2020;13: 667-673.

25. de Haan CAM, Kuo L, Masters PS, Vennema H, Rottier PJM. Coronavirus particle assembly: primary structure requirements of the membrane protein. J Virol. 1998;72(8):6838-6850.

26. Masters SP. The molecular biology of coronaviruses. Advances in Virus Research. 2006;66: 193-292.

27. Lalchhandama K. The chronicles of coronaviruses: the electron microscope, the doughnut, and the spike. Science Vision. 2020;20(2):78-92.

28. Neuman BW, Kiss G, Kunding AH, BhellaD, Baksh MF, Connelly S, et al. A structural analysis of $M$ protein in coronavirus assembly and morphology. Journal of Structural Biology. 2011;174 (1):11-22.

29. Woo PCY, Huang Y, Lau SKP, Yuen KY. Coronavirus genomics and bioinformatics analysis. Viruses. 2010;2(8):1804-1820.

30. Nieto-Torres JL, Dediego ML, VerdiaBaguena C. Severe acute respiratory syndrome coronavirus envelope protein ion channel activity promotes virus fitness and pathogenesis. PLoS Pathog. 2014;10(5):e1004077.

31. Chang CK, Sue SC, Yu TH. Modular organization of SARS corona virus nucleocapsid protein. J Biomed Sci. 2006; 13:59-72.

32. Zhou P, Yang XL, Wang XG. A pneumonia outbreak associated with a new coronavirus of probable bat origin. Nature. 2020; 579:270-273.

33. Paola S, Giovanni F, Alessandra PL. Whole genome and phylogenetic analysis of two SARSCoV2 strains isolated in Italy in January and February additional clues on multiple introductions and further circulation in Europe. Euro Surveill. 2020;25(13).

34. Shu Y, McCauley J. GISAID: Global initiative on sharing all influenza data-from vision to reality. Eur Surveill. 2017; 22:30494.

35. Pal R, Yadav U. COVID-19 Pandemic in India: Present Scenario and a Steep Climb Ahead. Journal of primary care \& community health. 2020;11:1-4.

36. Barry J, Fineberg VH, Sebelius K, Miller DA. Infected: A World in Peril, Is There a Way Out? Carnegie 2020 [June 02, 2020].

37. COVID-19 Coronavirus Pandemic. Worldometer. Available https://www.worldometers.info/coronavirus/ [accessed 01.12. 20].

38. Bradley M. The Essential Guide to the Wuhan Virus (Symptoms, Transmission and Prevention). Corona Virus; 2020.

39. Singh, AK, Pandey J, Adhikari IP, Gaur V, Kumar A, Prakash S. Assessment of Severity and Outcome of COVID-19 Cases by Haematological and Biochemical Markers at Tertiary Care Centre in India. Journal of Advances in Medicine and Medical Research. 2020;32(23):196-207.

40. Ministry of Health and Welfare, Government of India. COVID-19 India. Available online: https://www.mohfw.gov.in/ [accessed 01.12.2020].

41. Sanyal A. India Suspends All Tourist Visas Till April 15 Over Coronavirus: 10 Facts. NDTV.com. Retrieved 12 March2020. https://www.ndtv.com/india-news/coronavirusimpact-visas-to-india-suspended-till-april-152193382.

42. Coronavirus cases: Govt decides to lockdown 75 districts across country. The times of India. India. New Delhi. March 22 2020. Available online: https://timesofindia.indiatimes.com/ india/coronavirus-cases-lockdown-in-75-districtsto-be-announced/articleshow/74758646.cms

43. Omer BS, Malani P, Rio DC. The COVID-19 pandemic in the US: a clinical update. JAMA 2020; 323(18):1767-1768.

44. ICMR Testing Data. Dataset of ICMR tests (Every 24hrs Update) Available online: https://icmr.nic.in/ sites/default/files/whats_new/ICMR_testing_update _19April_9PM_IST.pdf. Accessed April 21, 2020.

45. Corona virus: Why is India testing so little?-BBC News. Available online: https://www.bbc. 
Amresh Kumar Singh et al; Sch J App Med Sci, Mar, 2021; 9(3): 312-321

Com/news/ coronavirus. [Accessed December 20, 2020].

46. Bherwani H, Gupta A, Anjum S. Exploring dependence of COVID-19 on environmental factors and spread prediction in India. NpjClimAtmosSci;. 2020; 3:38.

47. Ministry of health and family welfare. Govt. Of India. Available online: https://main.mohfw.gov.in/E-Citizen-and-

Tender/csma/maharashtra. Accessed on 03 December 2020.

48. Coronavirus: Karnataka becomes first state to invoke provisions of Epidemic Diseases Act, 1897 amid COVID-19 fear". Deccan Herald. Archived from the original on 22 March 2020. Retrieved 13 March 2020.

49. COVID-1 Information Website, Govt. Of Karnataka. Available online: https://covid19.karnataka.gov.in. Accessed on 03 December 2020.

50. Coronavirus: Karnataka shuts down schools, malls, theatres for a week". Livemint.com. 13 March 2020. Archived from the original on 14 March 2020. Retrieved 18 March 2020.

51. Karnataka closes border with Kerala after 6 COVID-19 cases reported in Kasargod". The Week. 21 March 2020. Retrieved 22 March 2020.

52. Coronavirus: Stranded migrant workers throng Delhi bus terminal in effort to get back home. India Today, New Delhi. Available online: https://www.indiatoday.in/india/story/ migrantworker-delhi-up-border-buses-coronaviruscommunity-spread-1660822-2020-03-29. Accessed on 29 March 2020.

53. COVID-19: 200 quarantined, contact tracing on after Delhi mosque gathering. Hindustan Times,
New Delhi. Available online: https://www.hindustantimes.com/indianews/police-cordon-off-part-of-nizamuddin-afterpeople-show-covid-19-symptoms/story-

ChOXzLNx3mS1490JgyquKK.html. Accessed on 30 March 2020

54. Home Ministry of Health and Family Welfare| GOI. http\\mohfw.gov.in.

55. https://www.thehindu.com/news/national/otherstates/one-fourth-of-uttar-pradeshs-active-COVID19-cases-are-in-eight-ncr-districts/ article 33149581.ece.

56. World Health Organization. Available online: https://apps.who.int/iris/handle/10665/330987.

57. https://www.businesstoday.in/coronavirus/secondCOVID-19-mutant-found-in-uk-even-moreinfectious-than-previous-strain/story/425839.html.

58. New coronavirus strain: Spain, Sweden and Canada latest countries to report cases of UK variant. Available online: https://scroll.in/latest/982418/newcoronavirus-strain-spain-sweden-and-canada-latestcountries-to-report-cases-of-uk-variant. Accessed on December 27, 2020.

59. New Covid strain may be in India already: Experts. Hindustan Times, New Delhi. Available online: https://www.hindustantimes.com/india-news/newcovid-strain-may-be-in-india-already-experts/story7ABVDSoUTigOot5BUuUhML.html. Accessed on December 23, 2020.

60. World Health Organization. Available online: https://www.who.int/docs/defaultsource/wrindia/situation-report/india-situationreport-44.pdf?Status $=$ Master\&sfvrsn $=22 \mathrm{cf} 15 \mathrm{ca} \_4$. Accessed on December 26, 2020. 